\title{
Middle-Ground Pragmatists: The Popularization of Philosophy in American Culture
}

George Cotkin

Pragmatism and middlebrow culture are presently two central but separate organizing themes for American intellectual and cultural life in the interwar period. During the 1920s and 1930s John Dewey's pragmatism dominated the intellectual landscape. Most intellectuals in the era had to work their way through, with, or around the edifice of Dewey's thought. ${ }^{1}$ At the same time many thinkers were taking another road, seeking to popularize knowledge for "middlebrow" consumers. As Joan Shelley Rubin has shown, such popularizers vigorously attempted to maintain authority and to mediate between genteel and modern culture by disseminating "high culture" to a mass audience. ${ }^{2}$

These two roads of thought, pragmatism and popularization, came together in the lives and thought of Irwin Edman, Will Durant, Horace Meyer Kallen, John Herman Randall, Jr., Harry A. Overstreet, and Thomas Vernor Smith. The work of these now largely forgotten popular pragmatists is important for a number of reasons. Although popular pragmatists shared many similarities with the general movement of middlebrow culture in the 1920 s, their need to popularize had specific institutional and political contexts. Popular pragmatists believed that professional philosophy was becoming too technical and confined to the corridors of academe. If pragmatism was

The author is deeply appreciative of the comments, criticisms, and support for earlier drafts of this paper offered by Casey Nelson Blake, David C. Harlan, David A. Hollinger, James Hoopes, Joan Shelley Rubin, Ann Schofield, Carolyn Stefanco, and David Thelen. Anonymous readers reports for $J H I$ have also been helpful. Finally, the research and writing of this essay were made possible by a National Endowment for the Humanities Fellowship.

1 On Dewey's centrality to this era, see Robert B. Westbrook, John Dewey and American Democracy (Ithaca, 1991), and Cornel West, The American Evasion of Philosophy (Madison, 1989).

${ }^{2}$ Rubin, The Making of Middlebrow Culture (Chapel Hill, 1992). 
to have cultural influence, then the philosopher had to make his work accessible to a wider public. The diffusion of such knowledge was a necessary precondition for democratic social reconstruction.

The popularization of pragmatism in the period after the First World War helped to create a new form of pragmatism, "middle-ground" pragmatism. If middlebrow culture attempted to balance demands for accessibility with quality and to reconcile authority with democracy, then middle-ground popular pragmatists wanted to retain the essentials of pragmatism as developed by Dewey while being open to new thinkers and concepts, especially those of George Santayana and the "tragic sense of life." While continuing throughout the mid-1920s to speak in the familiar language of social reconstruction, critical intelligence, and scientific method, middle-ground pragmatists increasingly emphasized a stance of moderation and distance later made famous in Walter Lippmann's A Preface to Morals (1929).

Middle-ground pragmatists also helped to define the chastened liberalism that dominated American intellectual life in the late 1940s and 1950s. It has become a commonplace in charting the history of American intellectuals to focus on how Reinhold Niebuhr, Daniel Bell, Lionel Trilling, and others, out of disillusionment with Marxism, adopted a new form of liberalism marked by irony, restraint, and disdain for utopian visions of social reconstruction. Rather than intending to refute the importance of this sea-change in thought, this essay suggests that middle-ground pragmatists antedated the move toward chastened liberalism by well over a decade, without any sustained engagement with radical politics. ${ }^{4}$

Middle-ground pragmatism proved to be an appealing position because it allowed young intellectuals to popularize philosophical ideas and to battle against the insufficiencies of American cultural life in the 1920s. As much a style of thinking as a specific philosophy, middle-ground pragmatism communicated philosophical knowledge and presented political positions in an ecumenical and non-threatening manner. The moderate liberalism and contemplative style of middle-ground pragmatism furthered its authors' cultural credibility and authority without alienating audiences with the shrillness of partisan politics. By the late 1920s and early 1930s the perspective of popular pragmatism was nestled between the exuberant democratic pragmatism of Dewey and the elitist distance of Lippmann, between the vitalism of James and the passivity of Santayana.

${ }^{3}$ Henry Samuel Levinson, Santayana, Pragmatism, and the Spiritual Life (Chapel Hill, 1992). See also Richard Wightman Fox, "Tragedy, Responsibility, and the American Intellectual, 1925-1950," in Lewis Mumford: Public Intellectual, ed. Thomas P. Hughes and Agatha C. Hughes (New York, 1990).

${ }^{4}$ On the chastened liberalism of a later generation, see Neil Jumonville, Critical Crossings: The New York Intellectuals in Postwar America (Berkeley, 1991), 102-50. See also Thomas Bender, "Lionel Trilling and American Culture," American Quarterly, 42 (1990), 324-47. 
Middle-ground pragmatists boasted highly respectable academic credentials. Durant, Randall, and Edman all received their Ph.D. degrees in philosophy from Columbia University; Randall and Edman continued to affiliate with the Columbia program, and each eventually headed the Department of Philosophy. Kallen studied with James (and Santayana) at Harvard and taught first at the University of Wisconsin before going to the New School for Social Research. In the 1920s Kallen collaborated with Dewey on a proposed project to examine the nature of American individualism. While Dewey withdrew from the project, Kallen completed it in a Deweyan spirit. Overstreet received his degrees from the University of California at Berkeley and Oxford, and for many years he chaired the philosophy program at City College in New York City. But he, too, was a devotee of Dewey. ${ }^{5}$ Finally, Smith received his Ph.D. in philosophy at the University of Chicago, where he spent many years teaching. Although a genial eclectic in his perspective, he was comfortable with the pragmatic perspective and identified Dewey, Mead, and Oliver Wendell Holmes, Jr., as formative influences. ${ }^{6}$

These popular philosophers, especially in their early work, drew from the thought of the pragmatic tradition. But pragmatism is not easily defined. H. S. Thayer effectively sums up pragmatism as "a theory of inquiry and judgment for which the logical characteristics and operations that issue in knowledge and in moral valuation and decision are integrally related." This definition plausibly captures the meaning and action continuum central to pragmatism. It misses, however, the cultural resonance of the pragmatist tradition in America. Here Richard Bernstein is more helpful by specifying anti-foundationalism, the fallible nature of truth, the social nature of the self, the importance of inquiry, and pluralism as the "constellation" of pragmatist ideas. From yet another angle pragmatism is a philosophical perspective closely intertwined with faith in science as an experimental method and open to revision in the light of the richness of experience. Dewey captured these imperatives with such terms as the "creative intelligence" and "warranted assertibility." The popular pragmatists worked within the outlines of these definitions of pragmatism and, in the process, helped to make pragmatism central to the conversation of American culture from the 1920s until the $1940 s^{7}$

${ }^{5}$ Biographical information on these philosophers is in American Philosophy Today and Tomorrow, ed. Horace M. Kallen and Sidney Hook (1935, Freeport, New York; rpt. 1968). On the Columbia University connection, see John Herman Randall, Jr., "The Department of Philosophy," in A History of the Faculty of Philosophy, Columbia University (New York, 1957), 102-45. Rubin in The Making of Middlebrow Culture interprets Durant as an idealist. For Durant as a pragmatist see Raymond Frey, William James Durant: An Intellectual Biography (Lewiston, N.Y., 1989), 37-47.

${ }^{6}$ Smith, A Non-Existent Man (Austin, 1962).

${ }^{7}$ Thayer, Meaning and Action: A Critical History of Pragmatism (Indianapolis, 1968), ix; Bernstein, The New Constellation: The Ethical-Political Horizons of Modernity/ Postmodernity (Cambridge, Mass., 1992), 326-29. On the cultural context of pragmatism 
Special conditions influenced the popularization of knowledge after the First World War. The 1920s were the great age of popularization. Although many values were wounded by the war, called into question by demographic shifts, or undermined by the development of industrial society, the value of education to liberate remained triumphant, a democratic article of faith for most Americans. The thirsting after knowledge on the part of the populace was not only satisfied but also increased by the variety of new modes of information. The communication explosion-larger format newspapers, new magazines, radio, and other forms of mass culture-mixed education with entertainment. ${ }^{8}$ As Dewey remarked in The Public and Its Problems (1927), democracy "will have its consummation when free social inquiry is indissolubly wedded to the art of full and moving communication.".9

Yet in the culture of the $1920 \mathrm{~s}$, the dissemination of ideas sometimes appeared as another form of crass consumerism. The casual ability to quote Spinoza or to display Durant's The Story of Philosophy on a coffee table became symbols of status and knowledge. Popular philosophy, like the popularization of knowledge generally in this period, could provide the data for cocktail party conversations, for would-be Jay Gatsbys trying to break into the high-society life of the mind.

Middlebrow mania for popularization, however, also allowed large numbers of reasonably educated Americans to pick their way through a mound of information with the help of experts who sought to separate the wheat from the chaff of literature, to condense the maddening crescendo of change into useful outlines, and to moderate between genteel and modernistic visions of culture. As Rubin notes, in the 1920s the number of college graduates had risen "from a half-million to more than one million," and high school enrollment in the same period more than doubled. ${ }^{10}$ While impossible to be assured about the audience that the popular pragmatists reached, they wanted to communicate with these newly minted college and high school graduates. In the opinions of reviewers the popular pragmatists often hit their mark, but one thoughtful commentator wondered "whether the persons who have read these books [of popular philosophy] have thereby increased their intelligence and understanding of science. We ought, at any rate, to give thanks to

see David A. Hollinger, "The Problem of Pragmatism in American History," In the American Province: Studies in the History and Historiography of Ideas (Bloomington, 1985), 23-43.

${ }^{8}$ Warren I. Susman, Culture As History: The Transformation of American Society in the Twentieth Century (New York, 1984), 105-21.

${ }^{9}$ John Dewey, The Public and Its Problems (1927) in The Later Works, 1925-1953 (Carbondale, Ill., 1988), 350.

${ }^{10}$ Rubin, Middlebrow Culture, 31. See also David O. Levine, The American College and the Culture of Aspiration, 1915-1940 (Ithaca, 1986). 
publishers and authors who are sufficiently adventurous to experiment with any means to satisfy the intellectual itches of potential learners." 11

Success at popularization for these philosophers began most famously with Durant's chatty, anecdotal best seller, The Story of Philosophy (1926). ${ }^{12}$ Popular works of philosophy by academically trained philosophers quickly became common coin in the publishing realm throughout the 1920s. Randall's The Making of the Modern Mind (1926) joined The Story of Philosophy as a selection of the Book-of-the-Month Club. At the close of the 1920s Randall published a massive tome on the development of the modern world. Edman produced a staggering range of publications, including a novel, an analysis of human nature, poetry, and a work on aesthetics. In this heady decade of popularization, Kallen published influential collections of essays on cultural pluralism and other topics (many of which first appeared in The Saturday Review of Books, The New Republic, and The American Mercury), and Overstreet became famous for his own best-selling "how-to" books on psychology. Finally, Smith not only authored many books and articles, he became a radio personality broadcasting philosophy through his "University of the Air" program.

The general contexts of a crisis of authority and a need to respond to the desire for information on the part of an increasingly educated audience certainly helped to shape the themes and style of the popular pragmatists. A reviewer recognized that in the wake of the First World War, in the midst of economic turmoil and massive social change, popular works of philosophy responded to "the demand for the reorientation of ourselves in relation to reality ... because of the collapse of the world-view inherited from the nineteenth century." 13 As Edman phrased it in "Philosophy for the Lawless" (1925), increased interest in popular philosophy represented "a search for a saving and reconstructive wisdom. From disrespect for the old foolish laws, we are turning to look for some law of reason to regulate our lives." 14

Another, more specific context helped to mold popular pragmatism. By the second decade of the twentieth century professional philosophy had become increasingly concerned with technical issues of epistemology and with problems in the philosophy of science. This technical turn was largely a response to a perceived crisis in philosophy. In the eyes of some, philosophy

${ }^{11}$ Eduard C. Lindeman, Review of Overstreet, Influencing Human Behavior in New Republic, 40 (26 May 1926), 40. Even the humanist critic Stuart Sherman praised popular philosophy; see his "Philosophy and the Average Man's Adult Education," New York Herald Tribune Books, 2 (20 June 1926), 1-3.

${ }^{12}$ On The Story of Philosophy, see Rubin, The Making of Middlebrow Culture, ch. 5; James D. Hart, The Popular Book: A History of America's Literary Taste (New York, 1950), 239; New York Herald Tribune Books, 2 (6 Feb. 1927), 20; 3 (30 Jan. 1927), 13.

${ }^{13}$ Review of The Enduring Quest in The Christian Century, 48 (6 May 1931), 615.

${ }^{14}$ Edman, "Philosophy for the Lawless," Bookman, 60 (Feb. 1925), 693. 
had relinquished its once exalted status as the queen of the sciences, dethroned by the physical and biological sciences and even threatened by its one time sub-discipline, psychology. Philosophy, once closely tied to theology and metaphysics and anchored in the pieties of an earlier century, had lost status. Some sought to retain philosophical credibility by employing the technical language of science, along with a rigorous logic. To hasten this transformation, philosophers increasingly specialized within the profession, publishing papers for other scholars in the rapidly expanding number of journals or presenting papers at scholarly conferences. In distancing itself from a public role, philosophy attempted to validate its professional credentials, develop its own special problems, and standardize and scientize its language and methodology for the solution of a new set of concerns. ${ }^{15}$

The vanity that philosophical analysis could be somehow abstracted from public life appalled Dewey and his followers. Dewey had, most famously in Reconstruction in Philosophy (1920), protested against over-reliance on "epistemological puzzles" which alienated many from philosophy. Dewey proclaimed that, in place of barren epistemology, "the task of future philosophy is to clarify men's ideas as to the social and moral strifes of their own day. Its aim is to become as far as is humanly possible an organ for dealing with these conflicts." 16 Alas, Dewey's turgid prose prevented him from effectively communicating his ideas to as wide an audience as he deserved. But he was sadly aware that "philosophic writing is often so specialized and technical that even educated readers, unless professionally trained, are repelled rather than attracted." 17

Durant attempted to expose the dangers of epistemology and to make philosophy address social and moral conflicts in a lively manner. Alone among the popular philosophers, Durant practiced his philosophical reflection outside a university setting. In his first and most pragmatistic book, Philosophy and the Social Problem (1916), Durant condemned the "epistemologs," who he felt dominated the discipline of philosophy. Informed action rather than pure theory was demanded of philosophy. Philosophy must be evaluated for its "vital use to the community" in the task of reconstruction. ${ }^{18}$

Durant's writings of the 1920s continued with these familiar pragmatic cavils against epistemology. Epistemological issues received short shrift in

${ }^{15}$ Bruce Kuklick, The Rise of American Philosophy: Cambridge, Massachusetts, 1860-1930 (New Haven, 1977), 451-80; Daniel J. Wilson, Science, Community, and the Transformation of American Philosophy, 1860-1930 (Chicago, 1990), 149-82.

${ }^{16}$ Dewey, Reconstruction in Philosophy (1920) in The Middle Works, 1899-1924 (Carbondale,Ill., 1988), 150, 94. Dewey did not ignore epistemology, see Ralph W. Sleeper, The Necessity of Pragmatism: John Dewey's Conception of Philosophy (New Haven, 1986). On Dewey as arch anti-epistemologist see Richard Rorty, Philosophy and the Mirror of Nature (Princeton, 1979).

${ }^{17}$ Dewey, "Foreword" to Durant, The Story of Philosophy (New York, 1926), n.p.

${ }^{18}$ Durant, Philosophy and the Social Problem (New York, 1928), 216, 219. 
The Story of Philosophy (Leibniz was ignored, Locke presented perfunctorily), while Kant and Descartes were examined not as epistemologists but as moral philosophers. In contrast, political and social thinkers such as Voltaire received more attention and praise. Durant concluded the volume by announcing that "Philosophy, like everything else, must secularize itself; it must stay on the earth and earn its keep by illuminating life... A philosophy so understood might at last produce philosophers worthy to be kings." 19

Overstreet agreed with Durant and Dewey that philosophy must move away from technical and unresolvable epistemological problems. Overstreet found modern academic philosophers often misled into believing that comprehension of "the ontological disquisitions of Descartes ... or the fantastical cosmologizing of Leibnitz" made one a real philosopher. Philosophy must be defined widely and understood as the attainment of greater wisdom. Overstreet imagined a sourcebook for philosophy where the familiar figures of Plato and Spinoza (like Durant he ignored Leibniz and Descartes) were joined by "the Shaws, Ibsens and Shakespeares, the Montaignes, Whitmans, Thomas Hardys and Mark Twains." Anyone was a philosopher "who has thought greatly, understandingly, about this business of life."20

Concerted attack on the conceits of professional philosophy did not bring forth the enmity of their professional brethren upon the heads of the middleground pragmatists. With the exception of Durant the popular philosophers were well-situated within the academy. Their books were usually reviewed positively in professional journals. Their ideas were further promoted by control of the important Journal of Philosophy, where the work of Edman, Randall, and others regularly appeared. In addition, Smith served for many years as editor of The International Journal of Ethics published out of the University of Chicago. In Kuhnian terms, while these philosophers were opposing a developing paradigm within the discipline of philosophy, throughout the 1920s and 1930s, they maintained powerful institutional and editorial connections that allowed their work to live both within and outside the academy. Academic connections actually lent an air of status and authority to their popularizations. ${ }^{21}$

${ }^{19}$ Durant, The Story of Philosophy, 574-75.

${ }^{20}$ Overstreet, "Can Philosophy Come Back?," The Freeman, 8 (12 Dec. 1923), 32435 .

${ }^{21}$ Of course not all philosophers were favorably impressed by this work. See the negative reviews by Mortimer Adler, "Sleight of Hand," Nation, 123 (29 Sept. 1926), 298-99; 1255 (12 Oct. 1927), 380-82, and Paul Weiss, "Human, All Too Human," New Republic, 47 (28 July 1926), 286. Favorable reviews are Stuart Sherman, "Philosophy and the Average Man's Education," 1-3; Ernest Sutherland Bates, "The Beauty of Philosophy," Saturday Review of Literature, 2 (3 July 1926), 899; and A. A. Roback, "Review," The Philosophical Review, 36 (1927), 191-92. 
Until the middle 1920s these philosophers labored comfortably in the pragmatist tradition. Edman's dissertation, published as Human Traits and their Social Significance (1920) was deeply pragmatist in style and assumptions. It was also highly popular, becoming a required text for the famous Contemporary Civilization course at Columbia University. Edman's pragmatism brought together James's psychology and Dewey's ideals of education, social reconstruction, and scientific method. Edman concluded his text in Deweyan fashion: "Education ... is the instrument through which the young can be educated not only to ideals and customs already current, but to their reflective modification in the light of our ever-growing knowledge of the conditions of human welfare." 22

No popular philosopher of the period dazzled more with his learning and expressed pragmatic ideals more fully than John Herman Randall, Jr., who published The Problem of Group Responsibility to Society (his 1922 Columbia University dissertation), The Making of the Modern Mind (1926, his most popular) and Our Changing Civilization (1929, in large part a rehash of themes in the earlier works). ${ }^{23}$ These books exuded immense erudition and authority, especially remarkable since Randall was only in his twenties during this decade.

The origin of The Making of the Modern Mind was, as with Edman's book, tied to the Contemporary Civilization course at Columbia University in the 1920s. Randall was one of the primary instructors for the course, which was designed, in Deweyan fashion, to introduce students to contemporary problems with an eye toward the intelligent reconstruction of society according to scientific and humane principles. The Making of the Modern Mind was written and organized for accessibility, with clearly outlined chapters and separate topic headings. Each chapter conveniently concluded with "Selected Reading Lists" broken down by subject for readers to pursue further, independent study.

The Making of the Modern Mind and Our Changing Civilization effectively claimed that intelligent reconstruction might overcome tensions between tradition and modernity - "Our machinery is modern; but our institutions are medieval."24 Randall worried that peasant "folkways" inhibited adjustment and progress. Hope for the future of society lay in continued scientific advancement and the withering away of unworthy, traditional

${ }^{22}$ Edman, Human Traits and their Social Significance (Boston, 1920), 459; Justus Buchler, "Reconstruction in the Liberal Arts" in A History of Columbia College on Morningside, ed. Dwight C. Miner (New York, 1954), 100-101.

${ }^{23}$ Although Randall has often been identified more as a naturalist than a pragmatist in his philosophy, he noted that "my own philosophizing is judged, I believe, and probably rightly, to be a pushing of certain aspects—the more metaphysical and realistic aspects—of John Dewey's." See Randall, "Towards a Functional Naturalism," in Contemporary American Philosophy, ed. J. E. Smith (London, 1970), 60.

${ }^{24}$ Randall, Our Changing Civilization (New York, 1929), 7. 
beliefs..$^{25}$ Yet Randall was neither a technocrat nor a booster of business civilization. Although traditional religions were riddled with superstition and prejudice, Randall maintained that a combination of faith, education, and the creative intelligence should direct the development of human society: "We need faith ... faith that the best that is old can be embodied in one life with the promise of the new." This would be achieved in Deweyan fashion by working to "devise more adequate means for bringing intelligence to bear on the organization of the new civilization." 26

While Overstreet identified himself with Dewey's pragmatism, he stressed that social reconstruction - the "bringing intelligence to bear on the organization of the new civilization"-must begin with the individual. Immensely confident and glib, Overstreet sought to become a doctor for the lost souls of America - those individuals unable to clear their minds, to gain an understanding of their "true" selves. To be sure, Overstreet was an inspiring teacher, blessed with massive reserves of good will and humor. If Dewey was to be the prophet of social reconstruction through an understanding of modern psychology, then Overstreet seemed perfectly content to be the crown prince for a psychological reconstruction of the individual.

Both Influencing Human Behavior (1926) and About Ourselves (1927) were brilliant works of popularization in the pragmatic mode. Written in a highly colloquial tone, Overstreet's books attempted to make the reader feel as if he or she were present at a lecture. Overstreet borrowed from an eclectic range of thinkers, behaviorists such as Watson and Pavlov, Freudian theorists (he actually preferred Alfred Adler's emphasis upon the self as motivated by a desire for respect rather than sexual gratification), James, for his emphasis upon the constructive role of habit formation, and Dewey, for his familiar characterization of mind as a seeker after ends. In the process Overstreet papered over technical disagreements with infectious enthusiasm designed to promote mental health more than psychological synthesis.

Technique in these books often overwhelmed content. Overstreet offered a door-to-door salesman's banter as an effective example of how to get people's attention. Influencing Human Behavior explained how capturing the interest of listeners was a key to successful public speaking and how striking metaphors made for compelling writing. Even science and philosophy became appealing when the writer on these subjects avoided the dull facts of the past and began "at the point where philosophy makes a difference." ${ }^{27}$

${ }^{25}$ Randall, The Making of the Modern Mind (Boston, 1926), 5.

${ }^{26}$ Randall, Our Changing Civilization, 359-61. See also Randall, "Effects of Science and Industry on Religion," Current History, 30 (1929), 355-62. In Why Religion, Kallen also attributed many religious problems to the development of an industrial, urban society. Kallen treated the crisis of individualism as a function of the same technological, demographic shift. Kallen, Why Religion (New York, 1927) and Individualism: An American Way of Life (New York, 1933).

${ }^{27}$ Overstreet, Influencing Human Behavior (1926, New York; rpt. 1953), 118. 
Scientists and philosophers influenced human behavior, according to Overstreet, by "capturing attention," by revising the habits of individuals in a desired direction, and by "deliberately setting out to develop-in ourselves and in others - the creative type of mind." Such maxims were reminiscent of the ideas that William James had set forth in the famous chapter on habit in his The Principles of Psychology (1890). ${ }^{28}$

Overstreet's popular psychology places him among the cultists of personality that historians view as central to the 1920s. According to this hypothesis, personality came to replace character as the mark of the modern individual able most successfully to fit the demands of a consumer society. ${ }^{29}$ Yet Overstreet tried to avoid such consequences. Reviews of his work in both popular and professional journals were invariably favorable, emphasizing how Influencing Human Behavior was not concerned with the goal of "selfaggrandizement." Although his insights could be used for selfish purposes, he was seen as helping individuals develop values that would aid society. About Ourselves was largely devoted to giving individuals the confidence to overcome repression and prejudice and to even "increase our sales resistance." Overstreet simply hoped that his ideas might help individuals "to search out the psychological and social means to a more adequate human life. $" 30$

The imperatives behind the early works of Durant, Edman, Randall, and Overstreet, then, were pragmatic, expressive of the ideals of social reconstruction, respectful of scientific method, and dedicated to furthering the popularization of knowledge. Similar concerns also permeated the work of other middle-ground pragmatists Thomas Vernor Smith and Horace Kallen. Smith, trained at the University of Chicago with Mead, intended in his early works to strengthen democracy by adopting an experimental stance toward social problems. In "The Trend in Philosophy" (1923), Smith summed up

${ }^{28}$ Overstreet, Influencing Human Behavior, 275. James, The Principles of Psychology (Cambridge, Mass., 1981), 109-31. On habit in James's life and philosophy, see George Cotkin, William James, Public Philosopher (Baltimore, 1990), 64-72.

${ }^{29}$ Warren I. Susman, "'Personality' and the Making of Twentieth-Century Culture," in New Directions in American Intellectual History, eds. John Higham and Paul K. Conkin (Baltimore, 1979), 212-26. See also, T. J. Jackson Lears, "From Salvation to SelfRealization: Advertising and the Therapeutic Roots of the Consumer Culture, 1880-1930," in The Culture of Consumption, ed. Richard Wightman Fox and T. J. Jackson Lears (New York, 1983), 1-38.

${ }^{30}$ Typical reviews of Overstreet's volumes are: Eduard C. Lindeman, "Psychology Put to Work," New Republic, 40 (26 May 1926), 40-41; Albert J. Levine, "Influencing Human Behavior," The Nation, 122 (5 May 1926), 508-09; Overstreet, Influencing Human Behavior, 277. Overstreet's emphasis upon personality as a means of contesting aspects of capitalism is strikingly similar to the cult of personality developed by Lewis Mumford, Randolph Bourne, and others in this period. See Casey Nelson Blake, Beloved Community: The Cultural Criticism of Randolph Bourne, Van Wyck Brooks, Waldo Frank, \& Lewis Mumford (Chapel Hill, 1990). 
his pragmatic perspective: "Thinking is more and more accepted as exclusively instrumental - instrumental to action and to the immediate values thereof." 31

Kallen had delineated the wide application of pragmatic method in William James and Henri Bergson (1914), proclaiming that "pragmatism is not merely a new name for old ways of thinking; it is a new name for all ways of thinking" predicated upon pluralism and perspectivism. ${ }^{32}$ Kallen popularized the term "cultural pluralism" in the essay "Democracy versus the Melting Pot," (1915) reprinted in his popular collection of essays Culture and Democracy in the United States (1924). He presented America in the metaphor of an orchestra marked by "a multiplicity in a unity, an orchestration of mankind ... in the symphony of civilization ... the range and variety of the harmonies may become wider and richer and more beautiful—or the reverse." 33 But whatever the resulting sound, Kallen never demurred from a willingness to have all particular ethnic groups sing in their own voices.

However well established their pragmatic pedigree and credentials might be, these thinkers increasingly came to a middle-ground position by the mid1920s and early 1930s. The twin Gods of pragmatism, James and Dewey, began to share space with other thinkers such as George Santayana and Oliver Wendell Holmes, Jr. In using the ideas of these thinkers, middle-ground popular pragmatists revised their earlier ideas. At the same time they reinforced their popular image as cosmopolitan thinkers, wedded to the pragmatist tradition, but open to the realities of limitation and tragedy that Santayana and Holmes seemed to express.

Movement toward middle-ground pragmatism happened for a number of reasons. Popular pragmatists wanted desperately to be viewed as cosmopolitan intellectuals. "Cosmopolitanism," as David A. Hollinger uses the term, allowed a developing American intelligentsia to think in universalist terms, free from the narrowness of particular ethnic identities. In Hollinger's lexicon cosmopolitanism is distinguished from Kallen's "cultural pluralism," in which ethnic particularism continued to flourish. ${ }^{34}$ Both forms of cosmopolitanism were present among middle-ground pragmatists, but for them cosmopolitanism was also an intellectual and cultural style, marked by sophistication and wisdom. The intellectual remained actively engaged in public issues but in a moderate and restrained manner.

${ }^{31}$ Smith, "Democracy as a Form of Experimentalism," Open Court, 36 (1922), 33945; "The Trend in Philosophy," The Christian Century, 40 (11 Oct. 1923), 1302; "Dewey's Theory of Value," The Monist, 32 (1922), 339-54; "Professional Work as an Ethical Norm," The Journal of Philosophy, 22 (2 July 1925), 365-72; "Philosophical Ethics and the Social Sciences," Social Forces, 7 (1928), 17-24.

${ }^{32}$ Kallen, William James and Henri Bergson (Chicago, 1914), 13.

${ }^{33}$ Kallen, Culture and Democracy in the United States (New York, 1924), 125.

${ }^{34}$ Hollinger, "Ethnic Diversity, Cosmopolitanism, and the Emergence of the American Liberal Intelligentsia," in In the American Province, 56-73. 
Santayana came to be seen by the popular philosophers as a model of cosmopolitan "world weariness" that lent credibility to their need to appear as calm, detached observers of the human condition. Santayana appeared usefully to correct the buoyant optimism of Dewey; he helped popular pragmatists to examine issues of art, faith, and human limitation, which had occasionally been exiled to the periphery of pragmatism. Santayana was particularly helpful for thinkers such as Edman and Kallen. He took the edge off their earnestness for social reconstruction and allowed them to feel comfortable as cosmopolitan intellectuals, discoursing about art, challenging the dangerous tendencies of "Ku Klux Klanism" for American cultural pluralism, and even allowing them to ruminate about the existential nature of life. ${ }^{35}$

Yet to the popular philosophers in the 1920s, the appeal of Santayana and Holmes, while sobering, did not destroy or even damage the essentials of their pragmatism or political liberalism. Although Santayana has long been seen as anathema to pragmatism and liberal politics, Henry Samuel Levinson has argued that Santayana was actually a "pragmatic naturalist," whose well-known disputes with pragmatists such as James and Dewey obscured philosophical affinities. ${ }^{36}$ Similarly, legal scholar Thomas Grey has made a strong case for placing Holmes within the pragmatic tradition, while David A. Hollinger has demonstrated the varied reasons for Holmes's popularity among liberals. ${ }^{37}$ The issue at hand is not the validity of these claims. In practice middle-ground pragmatists contrived to make Santayana's naturalism become an ally for their pragmatism. Holmes represented for middleground pragmatists such as Smith an exemplar of the clear-thinking, nononsense individual, with a sober view of reality.

Ideas borrowed from Santayana and Holmes also helped to supply the popular pragmatists with ammunition to fend off criticisms that had been leveled for years against pragmatism by Randolph Bourne, Van Wyck Brooks, and Lewis Mumford who considered that among pragmatism's deficiencies were James's recourse to the "cash value" metaphor and Dewey's support for the First World War. Critics of the "pragmatic acquiescence" also protested against pragmatism's presumed lack of values, instrumentalist and behaviorialist logic, naive faith in scientific method, and lack

${ }^{35}$ Kallen, "Culture and the Ku Klux Klan," in Culture and Democracy, 42. Edman's published Arts and the Man (New York, 1928), and a Santayana-style novel Richard Kane Looks at Life (London, 1926). Kallen's cultural criticism appeared in Indecency and the Seven Arts, and Other Adventures of a Pragmatist in Aesthetics (New York, 1930). His chief contribution to aesthetics was his two-volume Art and Freedom (New York, 1942).

${ }^{36}$ Levinson, Santayana, Pragmatism, and the Spiritual Life, passim.

37 Thomas C. Grey, "Holmes and Legal Pragmatism," Stanford Law Review, 41 (1989), 787-863, and Hollinger, "The 'Tough-Minded' Justice Holmes, Jewish Intellectuals and the Making of an American Icon," in The Legacy of Oliver Wendell Holmes, Jr., ed. Robert W. Gordon (Stanford, 1992), 216-28. 
of poetic vision. By the 1930s, in the face of totalitarian pressures, charges of relativism would be leveled against pragmatist philosophy. ${ }^{38}$

These were severe charges, but middle-ground pragmatists believed that they could have the best of both possible worlds since their perspective was less a philosophical synthesis than a style of cultural criticism. Unlike more mercurial temperaments - such as Reinhold Niebuhr, whose sense of the tragic forced him to dismiss pragmatism-middle-ground pragmatists strove to be scientific and literary, committed yet distanced, and optimistic yet cautious. Middle-ground pragmatists believed they had achieved a cosmopolitan angle of vision that allowed them to maintain their cultural authority and popularity without jettisoning either political interests or ironic distance.

Edman was certainly the most forthright popular pragmatist to adopt this position. Even in his dissertation, Human Traits, Edman had turned to Santayana for guidance on aesthetics and on the instinctual nature of human beings. Edman's naturalism was closely tied also to the pragmatic psychological tradition..$^{39} \mathrm{He}$ attempted to use the presence of instinct as an indicator of the natural limitations placed upon human beings, while also stressing, in good pragmatic fashion, that the human mind, through attention and habit, need not be bound by instinctual needs. Edman summed up the credo of his middle-ground pragmatism as early as 1925: "Nature and life are at bottom, if you will, meaningless, blind and chaotic. But they are malleable to an intelligence that faces them with candor and courage." 40

Edman's interest in Santayana continued unabated. In the mid-1930s he edited the Modern Library edition of The Philosophy of Santayana. In a lengthy introduction, Edman crisply accommodated Santayana's doctrines with pragmatism. To Edman, Santayana was essentially a moralist, "half skeptical, half pragmatic." While Santayana's detachment from moral issues in his later work seemed to go too far for Edman, Santayana's "earlier concern with the harmonising of impulse," with a naturalistic basis for all ideals, and with the consideration that the mind is an "efficacious instrument

${ }^{38}$ Robert Westbrook, "Lewis Mumford, John Dewey, and the 'Pragmatic Acquiescence," in Lewis Mumford: Public Intellectual, 301-22. On the relativism charge, see Edward W. Purcell, The Crisis of Democratic Theory: Scientific Naturalism \& the Problem of Value (Lexington, Ky., 1973), 139-58.

${ }^{39}$ On the connections between pragmatism and naturalism, see Harry Todd Costello, "The Naturalism of Frederick Woodbridge," and Harold A. Larabee, "Naturalism in America," in Naturalism and the Human Spirit, ed. Yervant H. Krikorian (New York, 1944), 295-353. Randall has stated that "Actually, Dewey and Woodbridge were very close together philosophically, in all but their very different languages. I long ago gave up trying to explain to students the precise difference." Randall, "Towards a Functional Naturalism," in Contemporary American Philosophy, 61. Randall, after his major works of popularization, turned increasingly to the history of philosophy, especially Aristotle. See his Aristotle (New York, 1960). For an argument that claims a Deweyan turn to Aristotle, see Ralph W. Sleeper, The Necessity of Pragmatism, 92-94, 97-98.

${ }^{40}$ Edman, "Philosophy for the Lawless," 697. 
for the realisation of human goods," represented the essential thrust of what was useful in Santayana's corpus. ${ }^{41}$

Even Santayana's "patrician" demeanor was valuable since it granted him a certain distance from the partisan fray of politics. The worth of distance, as Edman interpreted it, allowed Santayana to recognize democracy as an ideal, imperfect in practice but capable of improvement. In one stroke Edman had tempered Santayana's pronounced aristocratic proclivities and transformed him into a supporter of democracy. Edman could not ignore Santayana's increasing interest in "realms of being." Here too he made them pragmatic, finding that symbols "both foreshorten and focus complex experiences. Symbols become theories, presumptions, hypotheses. They are not only friends to free contemplation; they are guides to the harassed human, eloquent testimony of things absent and latent as well as vivid and pleasurable sensations of the mind." ${ }^{42}$ Edman had turned Santayana into a middleground pragmatist.

Durant was also attracted to Santayana's world view. He devoted an entire chapter to Santayana in The Story of Philosophy. In discussing Santayana, Durant touched upon the familiar: Santayana's poetic soul, epistemological skepticism, and naturalism. Durant pragmatized Santayana by arguing that he, like Dewey, distrusted epistemology. Santayana demanded that philosophy, in Durant's words, "come down from these [epistemological] clouds, and deal with the affairs of men." Durant was especially moved when Santayana called The Life of Reason "a name for all practical thought and action justified by its fruits in consciousness." Consciousness was in, not apart from, "the problems of contemporary life." ${ }^{43}$ Durant's early activism made him somewhat nervous around Santayana, "a man déraciné, a Spanish aristocrat exiled to middle-class America." Without recognizing a contradiction with his earlier characterization of Santayana's notion of consciousness as active, Durant criticized Santayana's "sombre withdrawal into himself; having taken life out of the world, he seeks for it in his own bosom." ${ }^{44}$ In 1926 Durant still wanted his philosophy home-grown, sober yet optimistically committed to the important tasks of personal as well as social reconstruction.

${ }^{41}$ The Philosophy of Santayana, ed. Irwin Edman (New York, 1936), xiii, xvi.

${ }^{42}$ The Philosophy of Santayana, xviii, xxvii, lvi. Santayana was well aware of Edman's using his philosophy for pragmatist ends. When the issue of having Edman as editor for a condensed edition of The Life of Reason was raised in the early $1950 \mathrm{~s}$, Santayana noted that "Edman would be a more zealous and reliable reviser: but, alas! I think he would retain ... all the pragmatisms, dogmatisms, and vulgarities that I should have expunged." Santayana to John Hall Wheelock, 24 Aug. 1951 in The Letters of George Santayana, ed. Daniel Cory (New York, 1955), 418.

${ }^{43}$ Durant, The Story of Philosophy, 536-38. Kallen had praise for Durant's treatment of Santayana. See his comments in Dialogue on George Santayana, ed. Corliss Lamont (New York, 1959), 93.

${ }^{44}$ Durant, Story of Philosophy, 550, 551-53. 
With publication of Durant's The Mansions of Philosophy in 1927 a new view suddenly emerged. Banished was the heady pragmatist optimism about social reconstruction that had dominated Philosophy and the Social Problem as well as the middle-ground pragmatism of The Story of Philosophy. The critique of technical, epistemology-centered philosophy remained, but now philosophy promised "total perspective" in the form of wisdom. Philosophy might transform "chaos into unity" and thereby achieve a reconstructive "healing unity of the soul." 45 Such a view, Durant maintained, was in consonance with Santayana's emphasis upon the Greek ideal of balance among the desires.

Yet even in this work Durant wanted popular philosophy to furnish middlebrow audiences with wisdom and perspective applicable to current issues. With a style at once sentimental and Olympian, Durant discussed the fate of the family in an age of changing social realities, the status of women's rights, love, aesthetics, and politics. He offered facile, conventional wisdom, ending by telling his readers and himself to "straighten our own lives with tolerance and honor." 46

Tolerance and honor now appeared as contemplative qualities, less important as values that allowed the individual to go forth into politics with reformist zeal. Durant preached a philosophy of near-resignation; moderation, maturity, and contemplation became ends rather than means. Whereas it was the stuff of youth to brim with fire and zeal for the problems of the world, the mature philosopher preferred to extol the virtues of wisdom as "a light, and not a fire; it illuminates the way, but it does not warm the heart, nor stir the soul to action." ${ }^{47}$

Durant had passed through his Sturm und Drang period. He now wanted, as he noted without Voltaire's saving grace of irony, "to cultivate his garden." By the late 1920s, moreover, Durant had swooned before the joys of fatherhood. In a particularly saccharine chapter, "I Become A Daddy," and in a thinly-veiled novel chronicling his life, Transition: A Sentimental Story of One Mind and One Era (1927), Durant seemed to have achieved peace with himself and the world through the marvelous dividends of fatherhood and maturity. ${ }^{48}$ But such recommendations were little more than patent medicines of resignation-indices of how far Durant had traveled from Dewey's ideals of social reconstruction. Yet even in resignation the ideal of the philosopher retained its power. The philosopher was empowered by distance from the tensions of the moment. It was unclear whether everyone could become a philosopher, but at least they might respectfully sit at the feet of great thinkers. ${ }^{49}$

${ }^{45}$ Durant, The Mansions of Philosophy (New York, 1927), vii-xi.

${ }^{46}$ Durant, Mansions, 426.

${ }^{47}$ Durant, Mansions, 621.

${ }^{48}$ Durant, Transition (New York, 1927).

${ }^{49}$ Durant, Mansions, 624-25. 
In some ways, Durant's adaptation of Santayana anticipated the highly influential A Preface to Morals (1929), in which Walter Lippmann contended that in the face of the "acids of modernity," modern men and women must attempt to develop a "matured personality" and think and act with "disinterestedness." In this formulation Lippmann was simply expanding upon ideals that he had popularized in the 1920s, when he emphasized that the public was inchoate and easily influenced by the media. Democracy in such a view was a sham. Only an elite, acting with objectivity and disinterestedness, should make decisions for the body politic. In this belief Lippmann and Durant were of one mind. Thus Lippmann's celebration of a stance of "disinterestedness" was only a shift in the grounds of argument from a strictly political venue to one that was moral and ethical. For Lippmann a mature and disinterested view of life might free the individual from unfulfilled and unrealistic desires. Accepting fate was useful if one were to "go quite simply about the business of the world." 50

Emphasis on moderation and distance did not have to translate, as it had for Durant, into a retreat from political engagement or a turn to elitism. After all, even Lippmann did not give up the ghost of politics; he simply believed that he only dropped utopian aspirations. It was in this sense-and with an uncompromising faith in popular democracy - that Thomas Vernor Smith read Santayana, Lippmann, and Holmes and assimilated them into his middle-ground pragmatism.

From Santayana, Smith gained, as he noted in his popular The Philosophic Way of Life (1929), an appreciation for the "aesthetic way of life," for poetry and the imagination and a vision of the tragic and ironic elements of life. Such perceptions - when tied to Smith's admiration for Santayana's "cosmopolitan perspective," marked by "a harmony of himself and with it a peace of mind ... matched by kindliness, good humor, and tolerance toward others"- defined Santayana's appeal. Certainly Santayana offered a powerful vision, but Smith eclectically combined it with the religious communalism of Josiah Royce, the scientific humanism of William James, and the "social way of life" of John Dewey. ${ }^{51}$

Smith came to view philosophy as "wisdom" as much as social reconstruction. In middle-ground fashion, wisdom was drained through the filter of pragmatism. Wisdom could never be absolute, built upon foundations of truth as dogma or even certitude. Meaning was won in a "tentatively and fumbling" manner. Maturity and imagination (central to Santayana and Lippmann) were balanced with the pragmatist emphasis upon experiment:

${ }^{50}$ Lippmann, A Preface to Morals (New York, 1929), 323-30. Lippmann's views on the public and the power of communications will be found in his Public Opinion (1922, New York; rpt. 1960) and The Phantom Public (New York, 1925).

${ }^{51}$ Smith, The Philosophic Way of Life (Chicago, 1929), 156; "The Role of the Philosopher," in Essays in Honor of John Dewey (New York, 1929), 363. 
"there is no conclusion to philosophy until all life is concluded." With James, Smith recommended a strenuous search for meaning, sobered with recognition of the limits placed upon human beings by nature. Out of this new sensitivity for limitation and tragedy might arise a judicious reformist and democratic way of life. ${ }^{52}$

By the mid-1930s Smith's middle-ground pragmatism was dominated by themes of creative skepticism, viable doubt, and compromise as the building blocks of the democratic and philosophic frame of mind. Many of these ideas Smith borrowed from Holmes. One chapter of Creative Sceptics (1934) was titled "Doubting One's Way to Democracy: Being a Super-Moral to Justice Holmes." ${ }^{53}$ Smith placed Holmes in the pragmatist camp because he held that " 'the workability of ideas' becomes the test, but not the meaning of truth." In addition Holmes exemplified middle-ground pragmatism by claiming "that no action can be great which is not informed with thought, redeemed from smallness by perspective." ${ }^{54}$

The consequences of Holmes's doubt and Smith's skepticism were "wise tolerance" and a spirit of compromise. Smith conveyed these messages to large audiences in his many books, radio programs, as well as political speeches. Only through discussion, detachment, and rational argument could democracy function. In a period when relativism was being condemned as unable to develop suitable principles to oppose totalitarian thinking of the right and the left, Smith's middle-ground pragmatism made the process - skepticism, tolerance, and compromise - more important than particular ends. Skepticism as a means, then, was an antidote to dogma and intolerance, as well as the basis for democracy. ${ }^{55}$

Smith had "learned that compromise is not only good for something, but it is also a good in itself." 56 The compromising spirit was as central in philosophical dialogue as in legislative negotiation. Although his experience was limited to a brief period as a State Senator in the Illinois Senate in the 1930s and to a single term as a Congressman-at-large from Illinois in the seventy-fourth congress, Smith believed that legislative compromise was the preferred course for the solution of America's problems. The perspective jibed nicely with the mediative emphasis in Jamesian pragmatism, with the social nature of man in Mead's version of pragmatism, and even in Holmes's

${ }^{52}$ Smith, The Philosophic Way of Life, 192, 178.

${ }^{53}$ Smith, Creative Sceptics: In Defense of the Liberal Temper (1934, Freeport, N.Y.; rpt. 1972), 177-209.

${ }^{54}$ Smith, Creative Sceptics, 198, 209-10 and "Justice Holmes: Voice of Democratic Evolution," in The Philosophy of American Democracy, ed. Charner M. Perry (Chicago, 1943), 119-52.

${ }_{55}$ Smith, Creative Sceptics, 231. On Smith's relativist defense of democracy, see Purcell, The Crisis of Democratic Theory, 208-10.

${ }^{56}$ Smith, A Non-Existent Man, 109. 
vision of distance as democracy's saving grace from "the decadence of romanticism." ${ }^{57}$ When compromise was absent from the political process, repression resulted as in the Soviet Union and Nazi Germany. ${ }^{58}$

In 1943 Smith published an expanded version of The Philosophical Way of Life in America. He still held to cosmopolitan ideals of tolerance, openness to diversity, and compromise: "A man of the world learns how to meet me halfway; and, from the vantage point of halfway, to see all the way into their characters. His is the resilient spirit." 59 Smith's philosophy of compromise and empathy would not survive intact the Second World War and the rise of communism. After all, as he had phrased it in Creative Sceptics, "Tolerance to all the tolerant; and intolerance only in defense of tolerance." 60

By the mid-1930s the essentials of middle-ground pragmatism were in place: respect for democracy, liberalism as a "fighting faith" based upon skepticism, reasonable tolerance, and an experimental attitude. In building up middle-ground pragmatism, these popular philosophers had included Santayana and Holmes into the pragmatic and liberal traditions in America. The resultant perspective was more pastiche than synthesis, but the demands of popularization required nothing more. Middle-ground pragmatists mainly desired a strong and accessible defense of liberal cosmopolitanism in a world beset with problems and challenges.

Perhaps Edman and Kallen carried these ideals most strongly into the decades from the 1930s to the 1950s. Even in the face of the greatest horrors of the twentieth century, Edman managed to maintain his equanimity. "What," he asked in 1939, "can we do to keep sane in a world gone mad?" In a moving piece subtitled "Postscript to Despair" he gained perspective from Santayana's naturalism: "Even if our worst fears are realized, Nature will still breathe easily, and generate new men in new times to have hopes and fears again." Edman found this "no small consolation," for "One of the

${ }^{57}$ Smith, "Justice Holmes: Voice of Democratic Evolution," 120.

${ }^{58}$ Smith, Creative Sceptics, 7-10.

${ }^{59}$ Smith, The Philosophic Way of Life, 217.

${ }^{60}$ Smith, Creative Sceptics, 260 . By the late 1940 s, Smith had joined other pragmatists and former radicals such as Sidney Hook and Overstreet in arguing that freedom of speech for communists was dangerous, since communists in America's classrooms would use that right to undermine freedom itself. In a host of articles, Smith attempted to defend the removal of presumed communists from the University of Washington. For Smith's views, see "Academic Expediency as Democratic Justice in re Communists," The American Scholar, 18 (1949), 342-53; "Democratic Compromise and the Higher Learning at Seattle," School and Society, 69 (26 Feb. 1949), 137-41. Hook, Heresy, Yes, Conspiracy No (New York, 1953), 21-23. For Overstreet's views, see Harry A. Overstreet and Bonaro W. Overstreet, Town Meeting Comes to Town (New York, 1938), and Harry and Bonaro Overstreet, What We Must Know About Communism (New York, 1958). On the movement from the left to the right, see John P. Diggins, Up From Communism: Conservative Odysseys in American Intellectual History (New York, 1975). 
advantages of detachment is that it makes us see how hasty our despairs have been, how provincial, even on the human scale, our assumption of tragedy. The darkness now seems absolute. Men before us have forgotten that it hides the morning star." $" 61$

Edman could not remain detached; he immediately headed in the direction of "the morning star." As America prepared to enter into the Second World War, Edman energetically composed Fountainheads of Freedom (1941), a book clearly designed to defend the intellectual integrity of liberalism and the dignity of man: "faith in the human dignity of each man in a society of brotherhood and freedom," Edman announced, will survive "the flames of destruction." ${ }^{2}$

Kallen has been described as "that rare philosopher, a pious pragmatist. The James in him is tempered by the Santayana." He became a leading spokesman for a liberal pragmatism opposed to totalitarianism in all forms. ${ }^{63}$ In a collection of essays published after the war Kallen found Americans facing an internal "crisis of freedom." This existential dilemma, Kallen argued in the now familiar language of middle-ground pragmatism, "may be overcome by faith acting without illusion." This new view was the "fighting faith" of liberalism, anchored by an oftentimes unreflective faith in tolerance, pluralism, and experimentalism, and tied to a belief that utopian illusions bred intolerance and thus undermined wise social policy. ${ }^{64}$

The thought of these largely forgotten thinkers, linking Dewey's energetic pragmatism and Santayana's distanced skepticism, bore striking affinities with the chastened liberalism of the 1940s and 1950s as developed most famously in Arthur M. Schlesinger, Jr.'s The Vital Center (1949), in Lionel Trilling's The Liberal Imagination (1950), and in the work of Reinhold Niebuhr and Daniel Bell. ${ }^{65}$ Middle-ground pragmatism did not initially grow out of disenchantment with Marxism. The origin for middle-ground pragmatism was shaped by the demands of popularization in 1920s America and the appeal of Santayana's vision of life. These factors combined to allow the middle-ground pragmatists to approach public problems with liberal solutions expressed in the language of philosophical wisdom.

Whatever problems may be connected with chastened liberalism as a

${ }^{61}$ Edman, Candle in the Dark: A Postscript to Despair (New York, 1939), 88.

${ }^{62}$ With the help of Herbert W. Schneider, Edman published the massive Fountainheads of Freedom (New York, 1941), a defense of democracy and pluralism dedicated to Dewey. The quote is found on page 192.

${ }^{63}$ Beryl Levy, Review of Kallen's Individualism: An American Way of Life in Journal of Philosophy, 30 (9 Nov. 1933), 640.

${ }^{64}$ Kallen, The Liberal Spirit: Essays on the Problems of Freedom in the Modern World (Ithaca, 1948), 8, 29. See also, Kallen, Patterns of Progress (New York, 1950).

${ }^{65}$ On this style of liberalism, see Jumonville, Critical Crossings; Richard H. Pells, The Liberal Mind in a Conservative Age: American Intellectuals in the 1940s and 1950s (New York, 1985); Richard Wightman Fox, Reinhold Niebuhr (New York, 1985), and Howard Brick, Daniel Bell and the Decline of Intellectual Radicalism (Madison, 1986). 
political position, middle-ground pragmatists always maintained that philosophy had a serious function within public culture. As Randall phrased it as late as 1963 , "Philosophy is not a narrow technical specialty appealing to a select few"; it was knowledge consequent to "any responsible and properly critical judgment of value." ${ }_{66}$ This imperative defined the work of the middle-ground pragmatists for over forty years. Perhaps most touching was their belief that each individual might be educated to think more deeply and tolerantly. In his quaintly appealing and popular autobiography, Philosopher's Holiday (1938), Edman captured this ideal when he recounted his associations with everyday, plebeian philosophers. One acquaintance, a wellread sailor, studied philosophy seriously, and expected it to offer him the wisdom with which to face life. ${ }^{67}$ If the middle-ground pragmatists in their many works of popular philosophy and political theory pushed sailors and others to contemplate more seriously the problems of life, then perhaps the legacy of these thinkers and the pragmatic tradition becomes more deserving of respect, especially when compared with the arcane language that informs so much of critical cultural discourse today.

California Polytechnic State University, San Luis Obispo.

${ }^{66}$ Randall, How Philosophy Uses Its Past (New York, 1963), 100, 14.

${ }^{67}$ See the chapter, "Philosophers without Portfolio," in Edman, Philosopher's Holiday (1938, New York; rpt. 1956), 146-59. 